\title{
Wybrane polskie rekomendacje onkologiczne w Internecie
}

\author{
Wojciech M. Wysocki
}

\section{Selected Polish oncology guidelines on the Internet}

W Internecie na polskich stronach odnaleźć można wiele źródeł specjalistycznej wiedzy medycznej z zakresu onkologii, dostępnych bez ograniczeń dla wszystkich zainteresowanych użytkowników. W bieżących odcinku niniejszego cyklu chciałbym zwrócić uwagę czytelników na — subiektywnie wybrane przeze mnie - dwa krajowe adresy internetowe.

Świetnie znane w środowisku onkologów są aktualizowane co 2 lata rekomendacje przygotowywane pod auspicjami Polskiego Towarzystwa Onkologii Klinicznej. Rekomendacje te po upływie stosunkowo niedługiego czasu od opublikowania ich w wersji książkowej są udostępnianie w Internecie całkowicie bezpłatnie i bez konieczności rejestracji. Materiałów tworzących ubiegłoroczne „Zalecenia postępowania diagnostyczno-terapeutycznego w nowotworach złośliwych (2013 r.)" trzeba szukać pod następującym adresem: http://onkologia.zalecenia.med.pl/. Na wskazanej stronie uporządkowano w układzie zgodnym ze spisem treści wersji książkowej oraz z zachowaniem podziału na tomy (tom I - nowotwory lite; tom II - nowotwory hematologiczne) kompletne rozdziały w formie plików pdf (ryc. 1). Kliknięcie wybranego tytułu powoduje otwarcie na ekranie komputera gotowego do czytania lub wydrukowania rozdziału. Niestety, na stronie nie ma możliwości przeszukiwania treści poszczególnych rozdziałów; nie ma także spisu treści obejmującego poszczególne podrozdziały. W sytuacji, gdy niektóre z nich obejmują bardzo obszerną tematykę (np. rozdział „Nowotwory przewodu pokarmowego" stanowi jeden duży plik obejmujący wszystkie nowotwory od przełyku do odbytu), odszukanie konkretnego, szczegółowego zagadnienia jest utrudnione.

Wartościowym sposobem wykorzystania zalet nośnika informacji takiego jak Internet jest możliwość — niekłopotliwej dla wydawcy — okresowej aktualizacji treści poszczególnych rozdziałów. W czerwcu i lipcu 2014 r. na omawianej stronie zamieszczono uzupełnione, zmodyfikowane wersje kilku rozdziałów poświęconych rakowi trzustki i brodawki Vatera, czerniakom skóry i mięsakom kości.

Strona zawierająca zalecenia PTOK nie została sformatowana z myślą o urządzeniach mobilnych, takich jak smartfony lub tablety, niemniej jednak wyświetlenie i nawigacja po

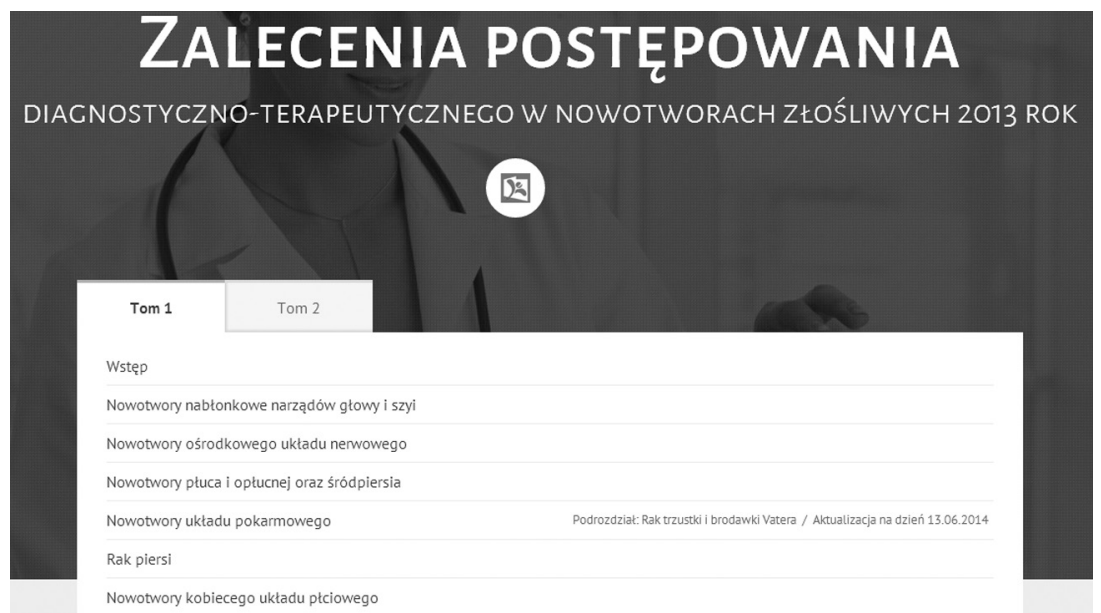

Rycina 1. Fragment strony zawierającej elektroniczną wersję książki „Zalecenia postępowania...., opracowanej pod auspicjami PTOK 


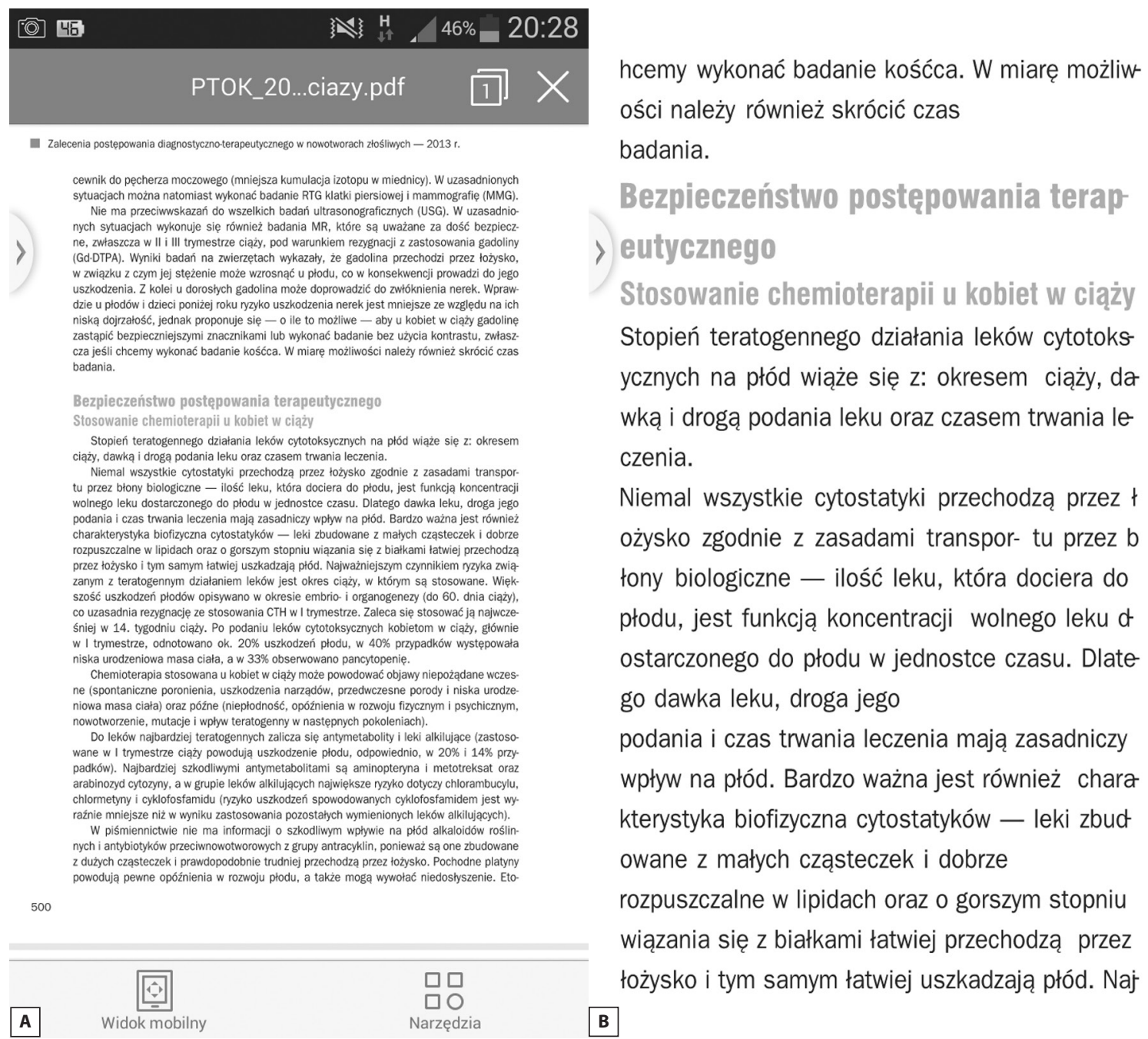

Rycina 2. Plik pdf z treścią zaleceń PTOK na ekranie smartfona w trybie klasycznym (A) oraz w trybie mobilnym (B)

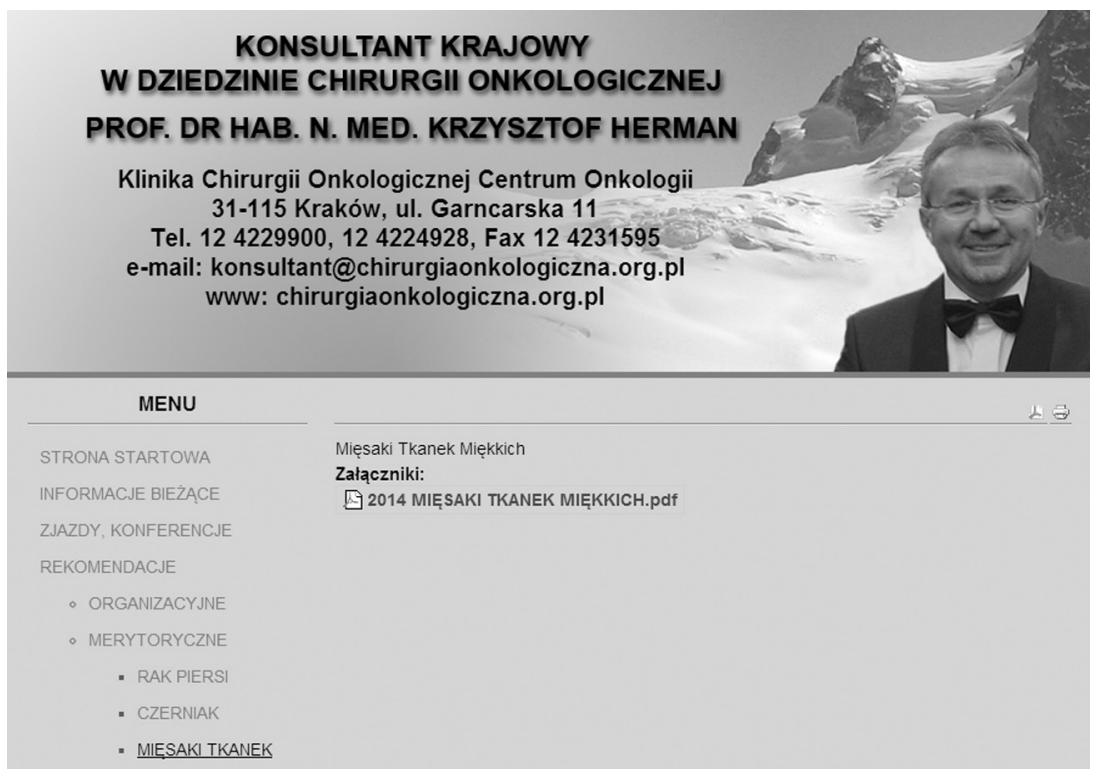

Rycina 3. Strona konsultanta krajowego $w$ dziedzinie chirurgii onkologicznej z częścią udostępnionych wytycznych 
jej zawartości za pomocą smartfona nie stanowi problemu. Co więcej, mimo iż klasyczne pliki pdf z treścią poszczególnych rozdziałów wyświetlone na małych ekranach urządzeń mobilnych mogą być niedostatecznie czytelne (ryc. 2A), to większość mobilnych czytników takich plików posiada przycisk pozwalający na automatyczne przekształcenie obrazu tekstu w postać wygodną do czytania na niewielkich ekranach (ryc. 2B). Dzielenie słów odbywa się, co prawda, bez poszanowania zasad polskiej pisowni, niemniej jednak tekst jest zrozumiały. Te wszystkie udogodnienia powodują, że z dostępnej w Internecie książki można korzystać nie tylko za pomocą komputera, ale również urządzenia mobilnego noszonego w kieszeni kitla lekarskiego.

Chciałbym zwrócić uwagę czytelników na inne źródło fachowej wiedzy onkologicznej udostępnione w Internecie. Na stronie www konsultanta krajowego w dziedzinie chirurgii onkologicznej (http://www.chirurgiaonkologiczna.org.pl/) zamieszczono rekomendacje merytoryczne dotyczące elementarnych reguł chirurgicznego leczenia chorych na wybrane, najczęstsze nowotwory złośliwe (ryc. 3). Bieżąca wersja zaleceń pochodzi z marca 2014 r.; wytyczne te są regularnie, corocznie aktualizowane. Rekomendacje te są zwięzłe i mogą stanowić przewodnik po diagnostyce i zasadach leczenia tych chorób. Zawartość rekomendacji jest - moim zdaniem — interesująca także dla onkologów niezabiegowych, pozwala im bowiem spojrzeć na postępowanie diagnostyczne i terapeutyczne oczami chirurgów onkologicznych. Na wskazanej stronie znajdują się również rekomendacje organizacyjne, opisujące warunki niezbędne w danym ośrodku do operacyjnego leczenia wybranych nowotworów złośliwych.

\section{Dr n. med. Wojciech M. Wysocki}

Centrum Onkologii — Instytut im. Marii Skłodowskiej-Curie Oddział w Krakowie

ul. Garncarska 11, 31-115 Kraków

e-mail:z5wysock@cyf-kr.edu.pl 